\title{
Redressing inequities of the past from a historical perspective: The case of the Olifants basin, South Africa\#
}

\author{
Barbara van Koppen* \\ International Water Management Institute, Southern Africa Regional Program, Private Bag X813, Silverton, South Africa
}

\begin{abstract}
This paper analyses the continuities and changes in water management in the Olifants basin after the first decade of implementation of the National Water Act (1998). By taking a historical perspective of the basin development trajectory, the paper shows how the White minority rulers, who exerted power until 1994, systematically denied historically disadvantaged individuals (HDIs) the right to become significant water users, let alone 'economically viable' water users. In contrast, White water users undertook major water resource development, which, by the 1970s resulted in the emergence of a 'White water economy'. Under the new dispensation (post-1994), the Department of Water Affairs and Forestry (DWAF) took a twopronged approach in the Olifants basin and elsewhere for redressing the inequities of the past. On the one hand, from the central top down, it opened up the 'White water economy' into a water economy serving especially 'economically viable water users', who rapidly ceased to be White only. As reflected in a range of new measures taken in the Olifants basin, in this new water economy DWAF better targets bulk domestic supplies to HDIs, has more public participation, and is strengthening its regulatory role in terms of cost-recovery, environmental issues, and pollution prevention. On the other hand DWAF seeks to fill the enormous backlog in water services delivery to HDIs, not only for domestic water uses, but increasingly also for productive uses. The major challenge of bottom-up coordinated service delivery for multiple uses through the newly established Provincial and Local Governments and the transforming line agencies is addressed under the recently launched Water for Growth and Development Initiative.
\end{abstract}

Keywords: water policy, water law, history, basin management, livelihoods, poverty, gender, Olifants basin, South Africa

\section{Introduction}

The Olifants basin is one of the two HELP basins in South Africa. The basin stretches from the small eastern part of Gauteng Province, via the western and middle part of Mpumalanga Province to the southern part of Limpopo Province into the Kruger National Park, before the Olifants River flows into Mozambique. Mean annual rainfall is in the range of $500 \mathrm{~mm}$ to $800 \mathrm{~mm}$ over most of the basin with wide annual and spatial variations (NWRS, 2004a). In order to mitigate these climatic vagaries, most water resources in the basin have been developed and competition for water among small rural users, urban users, mines, industries, large-scale agriculture, forestry, and eco-tourism is among the strongest in South Africa.

In spite of the high level of water development, poverty is widespread among the population of 2.5 million inhabitants and $32 \%$ of all households in the basin have no income at all. The annual incomes of another $30 \%$ of the households are less than 1 US\$ (approximately ZAR 8.00) per day (SSA, 2003; Magagula, 2006). Former homelands constitute only $26 \%$ of the area but house $60 \%$ of the population, all Africans. Africans constitute $94 \%$ and Coloureds and Indians $1 \%$ of the population. Whites are a minority of 5\% (Magagula, 2007). In this paper on the Olifants basin, the expression 'Historically Disadvantaged Individuals'

Revised paper. Originally presented at the symposium 'HELP in Action: Local Solutions to Global Water Problems - Lessons from the South' which was held at the Emperor's Palace, Johannesburg, South Africa from 4 to 9 November 2007.

* To whom all correspondence should be addressed.

욤 +2712 8459100; fax: +2712 8459110; mobile: +2782 8286750; e-mail: b.vankoppen@cgiar.org
(HDIs) mainly refers to Africans. Inequities in the distribution of water use are extreme. Over $95 \%$ of the water resources are controlled by only $0.5 \%$ of the population (Cullis and Van Koppen, 2007). Hardly any of the HDIs has a water entitlement in his or her name. Indeed, the key water challenge in this basin, as in many other basins in South Africa, is the improvement of the livelihoods of all, among others through stronger legal and realised water entitlements.

This challenge is recognised by the South African Government, including its Department of Water Affairs and Forestry (DWAF). Redressing the inequities of the past and poverty eradication are enshrined in the new Constitution (RSA, 1996). They are also the overarching objectives of the Water Services Act (1997) and the National Water Act (NWA) (1998). The formulation and promulgation of this widely renowned piece of water legislation were part and parcel of the broader watershed changes in South Africa since the first democratic elections in 1994.

After one decade of implementation of the Water Services Act and National Water Act in the Olifants basin, trends are emerging. As argued in this paper, these trends become considerably more visible by taking a historical perspective. History explains causes of the legacy of widespread poverty and inequities in access to water in the Olifants basin, as inherited from the past, and better highlights both the continuities and the changes overtime. The aim of this paper is to provide such analysis of the pre- and post-1994 'basin development trajectory' (Molle, 2003). The analysis is based on a literature review and interviews with policy makers, legislators, scientists, implementers, civil society, and the range of water users in the basin, including the poor, throughout this first decade of implementation. In the following, the history is addressed first before proceeding to the post-1994 era. Geographical sites are indicated by their current names. 


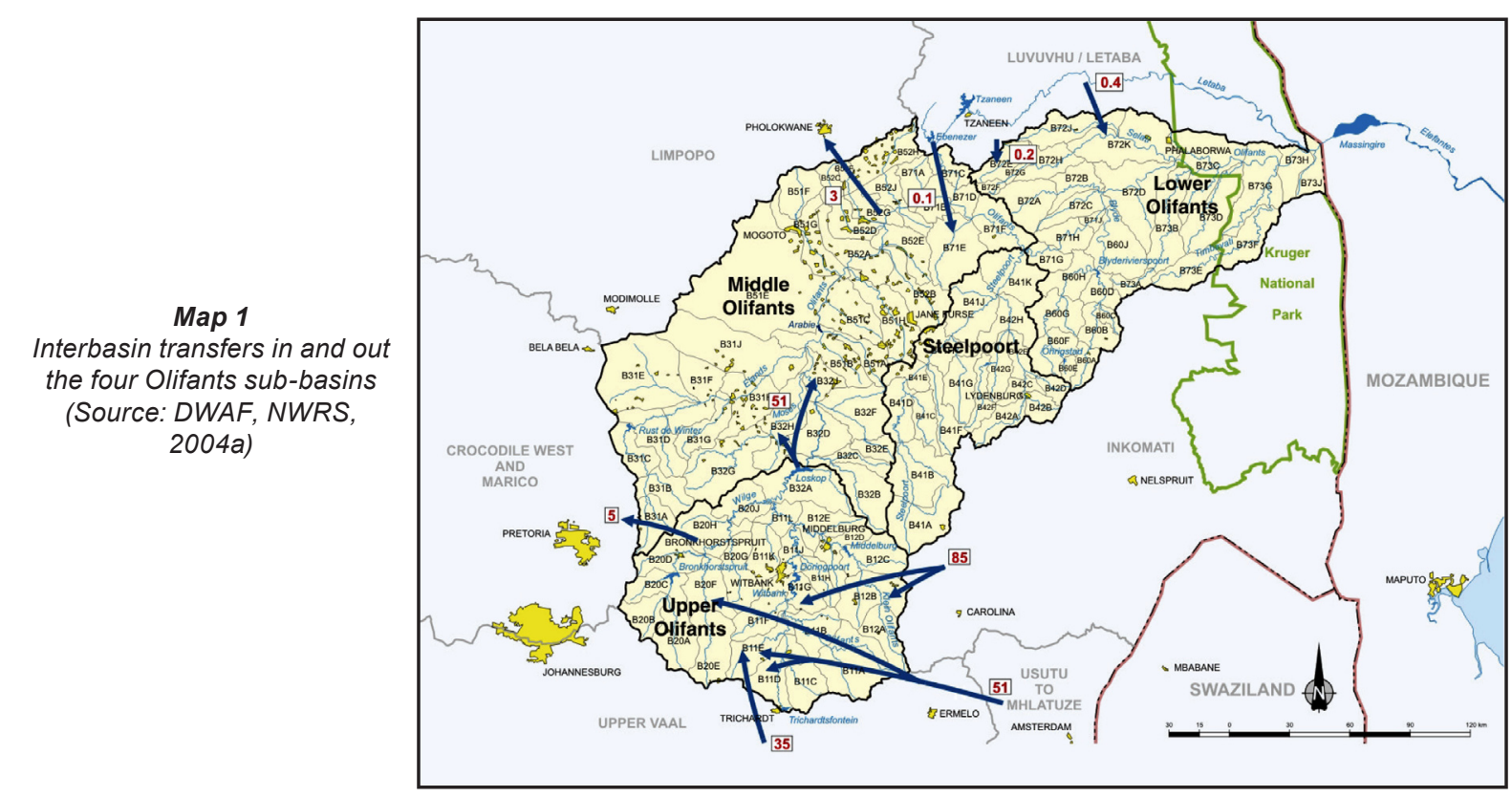

Map 1 shows the Olifants basin and its four sub-basins. It shows the extensive water transfers into the Upper Olifants subbasin, adjacent to Gauteng, underlining how important developments outside the Olifants basin have been.

\section{The Olifants Basin development trajectory pre-1994}

\section{Dispossession}

Three partly overlapping historical processes can be distinguished that explain the inequities in access to water and water entitlements at the dawn of democracy. The first process is the dispossession of Africans of their land, water, and mineral resources (Van Rheenen, 1925; Lewis 1934; O’Meara, 1983; Delius, 1983; Sparks, 1990; Backeberg, 1994; Thompson, 2001; Terreblanche, 2002). Originally, the Olifants basin was inhabited by agro-pastoralist Africans, the Sotho-speaking baSotho and baTswana and N'guni speaking N'debele, Swazis, and Tsongas. From the 1830s onwards, the Afrikaner 'Boers' started encroaching the area. They were agro-pastoralists and traders, among other in ivory (from the many elephants that gave the Olifants basin its Afrikaner name for 'elephant'. Its African name of Lepelle means 'the river that meanders slowly along' (Bulpin, 1956)). From the 1860 s onwards, some gold and diamonds were discovered in the Olifants basin, but much larger reserves were found in the adjacent Witwatersrand area in Johannesburg. This discovery incited the British mining and financing houses, supported by their motherland's imperial army, to annex the Boers and, together with the Boers, to subject all African chieftaincies with brutal violence. The defeat of chief Sekhukhune in 1879 marked this subjugation. Virtually all land was 'lawfully' appropriated by Whites through the British administrative land title deed system. Africans were relegated to 'Locations', the later Reserves and homelands.

In 1910 the elite 'alliance of maize (Afrikaner landlords) and gold (British mining houses and financing corporations)' established the Union of South Africa. This economic-politicalmilitary constellation, which continued largely unaltered when South Africa became a Republic in 1961 and lasted up till 1994, denied the vote to virtually all HDIs. The Land Act of 1913 'law- fully' dispossessed Africans of $91 \%$ of their land, slightly limiting to $87 \%$ under the Land Act of 1936 . The latter Act also further eroded tenants' status in White-owned farms to the most exploited wage labour force. The same dispossession occurred with regard to water resources. The Irrigation and Conservation Act of 1912 adopted the riparian rights principle, which ties rights in perpetuity to land ownership in White areas. This dispossessed Africans also from the land-related water resources with one stroke of the pen. A battery of 'draconian' labour regulations, including Master and Servant Acts, anti-unionisation acts, and pass laws, further subjugated Africans into an ultraexploited labour force for the White economy.

In this indirect divide-and-rule mode of territorial and institutional segregation, 'Pretoria' appointed ally chiefs in the Native Reserves, whose accountability became upwards instead of downwards to their constituencies as before this 'retribalisation'. The apartheid regime consolidated these Reserves as homelands through massive forced removals. In 1973, those with a Sotho surname, such as the Pedi, were moved to Lebowa. The supposed Tshwana were formally relocated into Bophuthatswana, one patch of which was adjacent to KwaNdebele in the Olifants basin. The N'debele in the Olifants basin, who had largely been living on White farms and in the urbanising and industrialising areas in the Upper Olifants sub-basin, got a new homeland: KwaNdebele. The Shangaan were placed near Mozambique, in the homeland of Gazankulu, at the eastern border of Lebowa. It is this 'lawful' dispossession of land, water, and mineral resources that explains why up till today hardly any of the HDIs in the Olifants basin (or elsewhere in South Africa) have formal water entitlements in their names.

\section{The White hydraulic mission}

The second process, 'the White hydraulic mission', explains the legacy of inequities in factual access to water and also shows the importance of state investments in water to steer patterns of agricultural growth. Water provision for White mining, electricity generation, urbanisation, and later industrialisation started localised and was often self-financed, also through local municipalities. However, for agriculture, the minority state was pivotal. From 1917 till 1994, the Irrigation Department and, after 1956, 
the Department of Water Affairs (DWA) provided technical support and very soft loans or grants to 17 newly created Irrigation Boards in the basin. In many cases this support included dam construction. After 1946, private farmers could also obtain subsidies. Moreover, in the 1930s the country's first two Government Water Schemes were built in the Olifants basin to settle White farmers: the Rust-der-Winter Scheme started in 1929 and the Loskop Scheme in 1934. This consolidated encroachment of the White minority in remote rural areas. Moreover, it quieted the political unrest of the dissatisfied 'poor Whites' many of whom had flocked to the urbanising centres where they competed with African wage workers with much lower wages (Backeberg, 1994; Terreblanche, 2002; Turton and Meissner, 2003).

Agricultural and irrigation support to Whites destroyed African farming even further. When the maize markets emerged at the end of the $19^{\text {th }}$ century, Africans, as traditional crop farmers, responded more vibrantly to these new opportunities than Afrikaner absentee landlords or agro-pastoralists. However, growing market competition by heavily subsidised White farmers' products compounded erosion of resource rights and degrading tenancy arrangements on White farms to such an extent that this ended the 'Black peasant road to capitalism' (Crais, 1992, cited in Terreblanche, 2002). Women as the traditional crop cultivators in the Native Reserves suffered most from this competition. Their output remained just sufficient to 'justify' even lower wages for males in their productive ages and saved the state any expenditure for raising the new generation of labourers, caring for the sick, and hosting the pensioners (Van Koppen et al., 2006). In probably no other era or country did state water policy influence the pattern of economic growth more than in pre-1994 agrarian South Africa.

Mining with its largely self-financed water provision was taken up in all four sub-basins since the late $19^{\text {th }}$ century. In the Upper Olifants sub-basin, coal was mined, which triggered the establishment of steam-driven electricity generation by the parastatal Electricity Supply Commission (Escom) in 1919. Cheap energy stimulated manufacturing and, in 1950, the establishment of the South African Coal, Oil and Gas Corporation (SASOL) and other petro-industries. In the mineral-rich Bushveld Igneous Complex in the Middle Olifants and Steelpoort sub-basins, the mining corporations started mining of platinum, asbestos, and many other minerals. Lastly, in Phalaborwa in the Lower Olifants sub-basin, just before the Olifants River enters the Kruger National Park, copper and phosphorus were mined.

\section{The White water economy}

The third process that shaped the legacy of the past started around the 1970s. A 'White water economy' emerged that focused on the construction and management of increasingly larger bulk infrastructure within and across basins and even across countries. The booming industrialisation and urbanisation since the 1960s in Gauteng and the adjacent Upper Olifants sub-basin warranted more and higher-security water.

Yet, on this elevated Highveld (from the east, the land rises over a mountainous escarpment towards the interior plateau known as the Highveld) only basins' headwaters were available. In 1974, the first water transfer into the Upper Olifants sub-basin was constructed. Increasingly complex inter-basin networks of pumping stations, reservoirs, canals, pipes and tunnels linked the Upper Olifants sub-basin further with the Vaal, Usutu, Tukela, and Inkomati basins. In the 1980s, planning for tapping the highest water tower in the region, Lesotho, was started. The two governments and the private sector established an independ- ent authority for the Lesotho Highland Project: the Trans-Caledon Tunnel Authority (TCTA). Financing was 'off-budget' from Treasury through a commercial loan of ZAR 10 billion (2000 prices) from the World Bank and other financiers. Apparently, these bankers were confident about the ability and willingness to pay of these economically viable water users.

Within the Olifants basin boundaries, the scale of infrastructure projects also became larger after the 1970s. In the Upper Olifants sub-basin, new large-scale water supplies provided water to KwaNdebele for domestic uses, besides White irrigation and mining (McCartney et al., 2004). In the Middle-Olifants sub-basin, the Flag Boshielo Dam was constructed in 1987 to ensure dry-season water storage for the growing number of mines in the area, for the municipal water needs of Polokwane town, and for irrigation immediately downstream of the dam. The planning for future pipes and dams was initiated. In the Lower Olifants sub-basin, the Blydepoort Dam was constructed in 1975 for White irrigators immediately downstream and the Phalaborwa mines much further downstream.

The higher costs of moving water from less favourable dam sites over greater distances, especially to elevated Gauteng warranted new notions of water resources management. This was first articulated by the Commission of Enquiry into Water Matters in 1970. Agriculture lost its favoured position. The construction of Government Water Schemes was ended and subsidies were challenged - although they continued in reality. This coincided with the agricultural transition and deregulation of agriculture within the colonial economy. Many White farmers had found better jobs in the industrialising economy. The remainder farms became highly mechanised and their sizes increased to an average of 808 ha (Mpumalanga Province) and 972 ha (Limpopo Province) (Fényes and Meyer, 2003). The irrigated area in the Olifants basin increased from 73638 ha in 1965-1973 (DWAF, 1991) to 128021 ha in 1995 (McCartney et al., 2004).

In the new philosophy, water was more and more seen as an economic good. The 1970 Commission reminded the repeated calls since the 1950s for economic tools: volume-based payment, sliding scales, and intra-scheme water trade for irrigation. Also, long before the Dublin Principles of 1991, notions emerged of virtual water and inter-scheme water trade according to the water's highest value: 'The application of a realistic price policy that reflects underlying scarcities is one of the most efficient ways of ensuring the effective exploitation of a country's resources. In a free economy it is moreover the best way of effecting a balance between supply and demand and preventing waste of a scarce commodity' (DWA, 1970). Furthermore, the urgency to implement 'the user pays' principle became stronger with reducing state funding when apartheid South Africa was confronted by economic stagflation, international boycotts and high state spending on the police and military to suppress the immense political protest within and outside South Africa. In the 1980s the then Department of Water Affairs (DWA) appointed its first accountants to ensure the factual repayment of loans.

Private engineering firms and consultants also came up with certain specialisations. The consultancy firm BKS specialised on the Olifants basin, for example. This organised fraternity claimed an important role for themselves according to DWA (1986): 'Except to the extent that it is necessary for security, strategic and practical reasons, the detailed design, construction and maintenance activities should be undertaken by the private sector'. According to this private sector, DWA should limit itself to 'those functions that are not economically viable or that achieve greater public benefits in the absence of commercial interests' (DWA, 1986). 
Under these changes, the role of DWA also shifted. Besides sharing in constructing, operating and maintaining the new bulk infrastructure alongside private players, DWA took up the centralised coordination and long-term planning of bulk supplies. Obviously, this occurred by taking the basin as unit of planning, but unlike much of the later global debates, with the purpose to move water in and out of those basins and out of other countries. A voluminous study was made on the Olifants basin as well (DWA, 1991). DWA also took up regulatory roles. As mentioned above, in order to reduce water uptake for irrigation (and repay loans) demand management through water pricing, sliding scales and trade were proposed. To save state funds, transfer of irrigation management was stimulated. Industrial pollution problems were also recognised. In the Upper Olifants sub-basin in particular, concerns were growing about the massive volumes of groundwater in abandoned coal mine shafts that had turned acid and gypsiferous. The apartheid government was also a global front-runner in recognising the 'environment' as a water user in its own right. In 1970, the 'environment' was defined as the Kruger National Park in the Olifants basin and St. Lucia wetlands. By 1986, some 300 small White-controlled public and private nature reserves were added. Their water needs were estimated to require $13 \%$ of the total nation's water demand (DWA, 1986). In any case, the drastic changes since the 1970s had rendered the 1956 Water Act with its many amendments outdated. An entirely new Act was needed (DWA, 1986).

\section{Deepening exclusion of HDIs}

The new notions of water as an economic good and economic viability as yardstick for fund and water allocation were promoted as blanket policies in 'the best national interest' of 'the free national economy'. This only disguised how it excluded HDIs even further.

In KwaNdebele, townships and in rural areas governed by co-opted chiefs, some mediocre public support was provided for domestic water supplies. In the face of the growing political protests in townships and payment boycotts because of weak service delivery, DWA recognised: 'Affordability is sometimes an important consideration in the allocation of the full cost of domestic supplies. This is particularly the case for the largest and fastest growing sector of the community, which generally has yet to advance from Third World economic conditions and which, in part, cannot afford the true cost of supplies to meet basic human needs' (DWA, 1986).

The 'Betterment policies' since the 1950s had supported the establishment of some 71 smallholder irrigation schemes in the homelands of the Olifants basin (Houghton, 1956; Denison and Manona, 2007). Yet, these and many unrecorded irrigation initiatives were not supposed to really compete with 'economically viable White farming'. As DWA stated: 'Irrigation development is often seen as an important first step in uplifting relatively undeveloped communities, but irrigation development is only one, and not necessarily the most effective, means of achieving socio-economic objectives'. 'Since economic advantage is the decisive criterion for successful irrigation, the actual cost of all inputs must be taken into account and proposed projects must be tested against strict efficiency norms'. Moreover, to protect the White markets: 'Besides the claims made on water of common interest and capital resources, the influence of irrigation on the balance between the demand and supply of agricultural products should also be taken into account' (DWA, 1986).

In sum, Africans were never meant to become significant water users, let alone 'economically viable' water users who would be able compete with Whites, whether on agricultural or water markets. Instead, the 1970s implied that the last favourable dam sites were taken up and any new water claim by HDIs had now to face a new user with stronger rights: 'the environment', as defined by White technocrats. Requests for factual financial support were downplayed by the new criterion of 'lack of economic viability'.

The 1970s and especially the 1980 s also saw the growing mass movements against the apartheid regime. The highly mechanised capital-intensive White economy started shedding increasingly larger parts of the population into unemployment, which added to its lack of legitimacy. In 1980, when the water planners argued for highest assurance of water supply to SASOL, this very symbol of the White economy was blown up by the underground military wing of the ANC (Saunders and Southey, 1998). National and international protests and boycotts against the racist apartheid regime made the country ungovernable and led to the negotiated settlement for democracy in the world's 'last nation'.

Under the new dispensation, the mission of the state changed radically from serving a small formal and well-organised White constituency to serving an entire nation of over 40 million citizens, deeply divided by wealth differences and territorial and institutional segregation. The despised homeland government structures were dismantled, although tribal chiefs maintained strong powers, in particular over communal land allocation. An entirely new nation-wide formal governance structure was set up. Provincial Government was established in nine new provinces. In 2000, Municipalities were demarcated, crossing former homeland boundaries and new provincial boundaries. The Olifants basin encompasses (parts of) 29 municipalities. In the efforts of the new Department of Water and Forestry to redress inequities from the past, two complementary approaches can be distinguished. The first is the opening up and gradual democratisation of the White water economy, initiated from the central level. The second approach focuses on factual water services delivery, mainly through the emerging Local and Provincial Government and line agencies. The following range of changes in the White water economy and in water services delivery post-1994 in South Africa in general and in the Olifants basin in particular is not exhaustive but serves to illustrate emerging patterns.

\section{Redressing inequities of the past post-1994}

\section{Democratisation of the White water economy}

One change in the White water economy throughout the country was that, with the growing Black middle-class, the water economy rapidly became less White-dominated, in terms of both clients and water professionals. These new clients were generally the 'economically viable' water users who could afford to pay water bills.

Second, subsidies to large-scale agriculture were factually reduced (which did not hamper self-initiated irrigation expansion, though).

Third, while the plans of the 1980s for bulk infrastructure development, operation and maintenance were largely pursued as foreseen, there were also changes. The new bulk schemes were directed more at providing domestic supplies. Within the Upper Olifants sub-basin, new water supply was constructed for domestic purposes to the former KwaNdebele homeland, and to surrounding industrialising and irrigation areas. More water kept coming from the Vaal-system. A pipe was constructed from 
the Vaal to SASOL and Eskom, and another pipeline to deliver water for domestic uses.

Dam development also became more participatory. In the Middle- and Steelpoort sub-basins, water provision for mining accelerated through one integrated program: the Olifants River Water Resource Development Programme. This included a pipeline from the Olifants River to mining ventures in the Steelpoort basin; the raising of the Flag Boshielo Dam by $5 \mathrm{~m}$; a pipeline from the Flag Boshielo Dam to mines in the adjacent basin; and, last but not least, the large De Hoop Dam in the Steelpoort area (DWAF, 2004b). These projects will make water available through off-takes and reservoirs for community water supply (DWAF, 2005), but the high price of this water is prohibitive. Public participation took place, also for the environmental impact assessment (EIA). The approval accommodated appeals by the Kruger National Park and four NGOs - who insisted on the implementation of the Ecological Reserve.

A $4^{\text {th }}$ change, nation-wide, was a more rigorous implementation of the 'user pays' principle. A central registration system for billing, the Water Authorisation and Registration Management System (WARMS), was set up. In the Olifants basin, some 1700 users (who often have more allocations) were registered. Two national pricing strategies were promulgated in 1999 and 2005 for Water Use charges, Water Resources Management charges and Waste Discharge charges.

Fifth, 'the environment' became a highly protected water user in its own rights. In the Olifants basin, the 'Ecological Reserve' was set at $460 \mathrm{Mm}^{3} / \mathrm{a}$ out of a natural mean annual runoff (MAR) of $2042 \mathrm{Mm}^{3} / \mathrm{a}$ (NWRS, 2004b), or 23\%. This rendered the Olifants basin over-allocated. The basic human needs component of the Reserve for $25 \mathrm{l} / \mathrm{cap} \cdot \mathrm{d}$ for a population of 2.5 million is $23 \mathrm{Mm}^{3} / \mathrm{a}$, which is $1 \%$ of the MAR of $2040 \mathrm{Mm}^{3} / \mathrm{a}$.

A $6^{\text {th }}$ change brought about more rigorous pollution prevention, besides the mentioned waste discharge charge. To remedy the acidification of groundwater in coal-mining shafts, DWAF promoted 'controlled releases' since the early 1990s. For new mines, pollution prevention was tied to new licences. In 2004, DWAF launched an 'Integrated Water Resources Management Plan for the Upper and Middle Olifants' (DWAF, 2004c).

Seventh, the Olifants became the $2^{\text {nd }}$ pilot project in the country, after the Inkomati, to establish a proposal for a catchment management agency (CMA), from 1999 to 2002 (Ligthelm, 2001). Small-scale water users in the former homelands were explicitly included in the deliberations (DWAF, 2003a). The resulting proposal was shelved, awaiting the lessons from early CMAs elsewhere, in particular the adjacent Inkomati basin, and national debates on institutional alignment in the water sector. Related to this were some (ineffective) efforts to transform Irrigation Boards into more equitable Water Users Associations (Faysse, 2004). More recent initiatives are to cluster WUAs.

The public participation of stakeholders from the Olifants basin in the formulation of the National Water Resources Strategy from 2002 to 2004, as prescribed by the NWA formed the $8^{\text {th }}$ change. Internal Strategic Perspectives for each basin, including the Olifants basin, constituted its components (DWAF, 2004a; 2004b).

Lastly, there were new civil society initiatives. In 1993 the Olifants River Forum was initiated by environmentally concerned representatives of the downstream Phalaborwa mines and the Kruger National Park. The aim of this (still largely White commercial) basin-wide forum is to pursue 'the health of the Olifants River'.

A common denominator of all these changes is that today's water economy of economically viable water users is less race- based and, thanks to DWAF's extensive efforts to achieve wide stakeholders' involvement, much more open than before 1994. Regulatory imperatives of cost-recovery with sound accountancy and effective pollution remedies and environmental flows are widely recognised, but enforcement appears to be a tall order. However, the beneficiaries have largely remained those who already benefited in the past and to a lesser extent the upcoming Black middle-class. For example, by 2006, out of the 1212 licences issued nation-wide in terms of the Act since 1998, only 26 (2\%) were for the HDIs (who constitute 91\% of the total population). Moreover, investments in water provision on the basis of cost-recovery and economic viability rendered resource-strapped Local Governments hesitant to spend their grants on domestic water services. If economic viability and cost-recovery are taken as criteria for investments in productive uses, the large majority of HDIs remains as excluded as before. In sum, the White water economy has definitely opened up, but is hardly democratised as yet.

\section{Water services delivery}

The $2^{\text {nd }}$ approach for redressing inequities from the past focuses on factual water services delivery to HDIs to overcome the enormous backlogs in access to water. The single most important challenge is the creation of effective service delivery structures after the apartheid structures had been abolished, especially in the former homelands, where $60 \%$ of the population in the Olifants basin lives.

Till the mid-2000s, virtually all water service delivery was focused on domestic water supplies. This utmost priority for domestic water services and sanitation was enshrined in the Water Services Act (1997) (RSA, 1997). Government's top priority was to bring, for free, $25 \mathrm{l} / \mathrm{cap} \cdot \mathrm{d}$ within $200 \mathrm{~m}$ from the house to all citizens (implying that higher consumption needed to be paid). DWAF itself temporarily filled the institutional void for service delivery as regional DWAF offices took over all ex-homeland schemes and its technical staff. Access to domestic water supplies improved considerably between the mid-1990s and mid-2000s, at least according to the design parameters of the infrastructure that was financed (which is considerably higher than actual end-use). Access to water improved from 59\% of the population in 1994 to $79 \%$ for Mpumalanga and $72 \%$ in Limpopo Province in 2005. Similarly, access to basic sanitation services improved to 59\% in Mpumalanga but only $37 \%$ in Limpopo (DWAF, 2006a). Preparing for hand-over of this servicedelivery function to Local Government in 2006, the shifting role of DWAF to one of regulation and support was enshrined in the Water Services Strategic Framework, approved in 2003 (DWAF, 2003b). The young Local Governments by that time received considerable subsidies through equity schemes, and after 2004, municipal infrastructure grants. Planning for this service delivery was designed to be bottom-up through Integrated Development Plans by municipalities and Provincial Growth and Development Strategies and Water Sector Development Plans by provinces. All plans should contribute to the nationally defined economic strategies. The overarching Governmental Relations Framework Act of 2005 stipulated these cooperative requirements further.

This temporary arrangement through DWAF cushioned the hurdles of the institutional transition from territorial and institutional segregation to nation-wide democratic government delivery structures. However, the hurdles could not be avoided. Since hand-over, confusion about responsibilities has affected service provision, leading to the vicious circle of lesser performance, 
so lesser incentive to pay or otherwise contribute to maintenance (Ladki et al., 2004; Post-Uiterweer et al., 2006). There are cases in which delivery performance has dropped below the levels of the apartheid era. Also, municipalities' engagement in water as a business tends to favour, again, income-generating sale of water rather than an holistic endeavour of support for the most appropriate technologies, e.g. mechanised pumps, homestead wells, rainwater and run-off harvesting, etc. As the $25 \mathrm{l} / \mathrm{cap} \cdot \mathrm{d}$ was strictly meant to be used for domestic purposes only, productive water needs were ignored, initially.

Service delivery for productive water uses was more problematic and lacked any temporary cushion. When the new Provincial Department of Agriculture in Limpopo Province took formal responsibility for the smallholder irrigation schemes, it withdrew all existing financial and technical support of the apartheid era for smallholder irrigation. As a result, many schemes partially or fully collapsed. In 2004 the Provincial Department of Agriculture launched a massive project, namely Revitalisation of Smallholder Irrigation Schemes (RESIS) to rehabilitate 126 schemes in Limpopo Province (also outside the Olifants basin) covering about 19730 ha for 12432 farmers (Shaker, 2005). The opportunities offered by smallholder irrigation for poverty eradication through broad-based economic growth were underlined: 'While mining provides 8 jobs/ZAR1m. invested, agriculture provides 40 to 50 jobs/ZAR1m. invested' (Shaker, 2005). However, by 2005 pressures to spend development budgets grew and the focus shifted to larger-scale 'farming as an economically viable business' (Magadzi, 2005). A similar move towards larger-scale business-like farming according to the sole yardstick of 'economic viability' was observed elsewhere in the national policies of the Department of Agriculture and Land Affairs, and also in land reform (Lahiff, 2007).

DWAF itself also started to support HDIs - reverting to its original role of pro-active investor in infrastructure but now targeted at HDIs, DWAF Head Office adopted a policy of 'Financial assistance to resource-poor irrigation farmers' (DWAF, 2004d). This programme enabled, among other, the roll-out of rainwater harvesting tanks in 26 villages in four provinces, including the Olifants basin in 2005/06.

However, for productive water uses, collaboration with other line agencies is indispensable. For this aspect of local development, bottom-up coordination had to take place through the above-mentioned new planning frameworks of the upcoming Local and Provincial Government. In order to forge these new collaborations and clarify mutual roles, DWAF reached out to Provincial and Local Government by organising Provincial Water Summits in 2005 and 2006, also in the Limpopo and Mpumalanga Provinces (basin boundaries were hardly seen as significant). Discussions during the summits on, for example, the internal strategic perspectives of the National Water Resources Strategy gradually drew Local and Provincial Government into holistic water management. Thus, an ever-growing array of aspects of water management other than just domestic water services delivery came on the agenda (DWAF, 2006b). The separation between domestic and productive uses appeared an artificial one, moving towards integrated 'multiple water use services' ('mus') (DWAF, 2006c).

The articulation of a bottom-up democratic planning and service delivery structure around an encompassing national economic plan provided, finally, a legitimate unitary government structure. DWAF formulated its sector leadership role ensuring the availability of a critical input to these economic strategies: water. From 2006 onwards, this new horizontal and vertical alignment from local to national level was phrased as 'Water for Growth and Development'. It absorbs the expanding 'economically viable' water economy and provides an umbrella for integrated service delivery, not only for domestic uses but also for productive uses and regulatory roles.

\section{Conclusion}

The many challenges to expand and regulate a sound 'economically viable' water economy receive much attention from DWAF and the rapidly growing consultancy and engineering firms. At the same time, the large majority of HDIs has yet to benefit from greater direct access to water for productive uses. Some have even lost their earlier access. Coordination among line agencies around Local and Provincial Government to this end appears tough. A similar nation-wide temporary arrangement to fill the backlogs and cushion the institutional transitions seems warranted. This can influence the pattern of growth. Even when such arrangements are put in place, the question in the stressed Olifants basin is whether such action will be in time, before the very last remaining water resources and affordable infrastructure development sites have been taken.

\section{References}

BACKEBERG GR (1994) Die Politieke Ekonomie van Besproeiingsbeleid in Suid-Afrika. Voorgelê ter Vervulling van 'n Deel van die Vereistes vir die Graad Philosophiae Doctor. Departement Landbou-Ekonomie, Voorligting en Landelike Ontwikkeling. Fakulteit Biologie en Landbouwetenskappe. University of Pretoria, Pretoria, South Africa.

BULPIN TV (1956) Lost trails of the Transvaal. Somerset, South Africa. Stephan Phillips Africana Series, Cape Town, South Africa.

BUNDY C (1988) The Rise and Fall of the South African Peasantry (2 ${ }^{\text {nd }}$ edn.) David Philip, Cape Town and Johannesburg, South Africa.

CRAIS C (1992) The making of the colonial order: White supremacy and black resistance in the Eastern Cape, 1770-1865. Johannesburg: Witwatersrand University Press. In: Terreblanche S (2002) A History of Inequality in South Africa 1652 - 2002. University of Natal Press, Pietermaritzburg, South Africa.

CULLIS J and VAN KOPPEN B (2007) Applying the Gini Coefficient to Measure the Inequality of Water Use in the Olifants River Water Management Area, South Africa. IWMI Research Report 113. International Water Management Institute, Colombo, Sri Lanka.

DELIUS P (1983) The Land Belongs to us: The Pedi Polity, the Boers, and the British in the Nineteenth-century Transvaal. Ravan Press, Johannesburg, South Africa.

DENISON J and MANONA S (2007) Principles, Approaches and Guidelines for the Participatory Revitalisation of Smallholder Irrigation Schemes: A Rough Guide of Irrigation Development Practitioners: Vol 1 and WRC Report No TT 309/07 Principles, Approaches and Guidelines for the Participatory Revitalisation of Smallholder Irrigation Schemes: Concepts and Cases: Vol 2 (WRC Project No. K5/1463/4). Water Research Commission, Pretoria, South Africa.

DEPARTMENT OF WATER AFFAIRS (1970) Report of the Commission of Enquiry into Water Matters. R.P. 34/1970. Pretoria, Republic of South Africa.

DEPARTMENT OF WATER AFFAIRS (1986) Management of the Water Resources of the Republic of South Africa. Department of Water Affairs, Pretoria, South Africa.

DEPARTMENT OF WATER AFFAIRS (1991) Water Resources Planning of the Olifants River Catchment. Study of Development Potential and Management of the Water Resources. Volume 3. Part 6. Basin Study Report. Situation Assessment: Subcatchment B500.: Theron, Prinsloo, Grimsehl and Pullen Consulting Engineers, Pretoria, South Africa.

DEPARTMENT OF WATER AFFAIRS AND FORESTRY (2003a) Establishment of a Catchment Management Agency for the Olifants Water Management Area. Prepared by Van Veelen M, Coleman T, Thompson H, Baker T, Bowler K, De Lange M and Sibuyi I. DRAFT 
Proposal to the Minister. Department of Water Affairs and Forestry, Pretoria, South Africa.

DEPARTMENT OF WATER AFFAIRS AND FORESTRY (2003b) Water Services Strategic Framework. Department of Water Affairs and Forestry, Pretoria, South Africa.

DEPARTMENT OF WATER AFFAIRS AND FORESTRY (2004a) National Water Resource Strategy (1st edn.) 2004. Department of Water Affairs and Forestry, Pretoria, South Africa.

DEPARTMENT OF WATER AFFAIRS AND FORESTRY (2004b) Olifants Water Management Area: Internal Strategic Perspective. Version 1. By GMKS, Tlou and Matji for the Directorate, Water Resources Planning. DWAF Report No. P BASIN 04/000/00/0304 Department of Water Affairs and Forestry, Pretoria, South Africa.

DEPARTMENT OF WATER AFFAIRS AND FORESTRY (2004c) Upper and Middle Olifants River Catchment: the Development of an Integrated Water Resources Management Plan. Directorate National Water Resources Planning, Department of Water Affairs and Forestry, Pretoria, South Africa.

DEPARTMENT OF WATER AFFAIRS AND FORESTRY (2004d) Policy on Financial Assistance to Resource-Poor Irrigation Farmers in Terms of Sections 61 and 62 of the National Water Act (1998). Department of Water Affairs and Forestry, Pretoria, South Africa.

DEPARTMENT OF WATER AFFAIRS AND FORESTRY (2005) Environmental Impact Assessment (EIA) (12/12/20/553) for Construction of Proposed Infrastructure for the Olifants River Water Resources Development Project (Phase 2) in terms of Section 22(3) of the Environment Conservation Act, 1989 (Act No. 73 of 1989) Summary Draft Environmental Impact Report. Prepared by ACER/ CSIR/Zithole/Golder. Olifants River Water Resources Development Project Department of Water Affairs and Forestry, Pretoria, South Africa.

DEPARTMENT OF WATER AFFAIRS AND FORESTRY (2006a) Water services. A National Perspective: Making it Happen. Directorate Water Services Planning and Information, Department of Water Affairs and Forestry, Pretoria, South Africa.

DEPARTMENT OF WATER AFFAIRS AND FORESTRY (2006b) National Water Summit 2006. 4-5 May, Gallagher Estates. Department of Water Affairs and Forestry, Pretoria, South Africa.

DEPARTMENT OF WATER AFFAIRS AND FORESTRY (2006c) Provision of Water for Small-Scale Multiple-Use Systems. A Guideline for Municipalities. Version 1. Department of Water Affairs and Forestry, Pretoria, South Africa.

FAYSSE N (2004) An Assessment of Small-scale Users' Inclusion in Large-scale Water User Associations of South Africa. IWMI Research Report 84. International Water Management Institute, Colombo, Sri Lanka.

FÉNYES T and MEYER N (2003) Structure and production in South African agriculture. In: Nieuwoudt L and J Groenwald (eds.) 2003 The Challenge of Change. Agriculture, Land and the South African Economy. University of Natal Press, Pietermaritzburg, South Africa.

HOUGHTON DH (1956) The Tomlinson Report. A Summary of the Findings and Recommendations in the Tomlinson Commission Report. The South African Institute of Race Relations, Johannesburg, South Africa.

LADKI M, SESHOKA J, FAYSSE F, LÉVITE H and VAN KOPPEN B (2004) Possible Impacts of the Transformation of Water Infrastructure on Productive Water Uses. IWMI Working Paper No. 74. CEMAGREF, Comprehensive Assessment of Water Management in Agriculture and International Water Management Institute Colombo, Sri Lanka.

LAHIFF E (2007) State, Market or the Worst of Both? Experimenting with Market-based land Reform in South Africa. Land Reform and Agrarian Change in South Africa. Occasional Papers Series No. 30. Programme for Land and Agrarian Studies. Western Cape School of Government, University of the Western Cape, Cape Town.

LEWIS AD (1934) Water law. Its development in the Union of South Africa. Juta and Co. Ltd., Cape Town and Johannesburg, South Africa.

LIGTHELM M (2001) Olifants Water Management Area: Catchment Management Agency Establishment. In: Abernethy Charles (ed.)
2001 Intersectoral Management of River basins: Proc. Int. Workshop on "Integrated Water Management in Water-Stressed River Basins in Developing Countries: Strategies for Poverty Alleviation and Agricultural Growth". Loskop, November 2001 Colombo, Sri Lanka: International Water Management Institute and DSE.

MAGADZI DP (2005) Budget Speech. Limpopo Department of Agriculture. Limpopo Department of Agriculture, Polokwane, South Africa.

MAGAGULA TF, VAN KOPPEN B, SALLY H (2006) Water Access and Poverty in the Olifants Basin: A Spatial Analysis of Population Distribution, Poverty Prevalence and Trends. Paper presented at 7th Waternet/ WARFSA/ GWPSA Symposium, 1-3 November 2006, Lilongwe, Malawi.

McCARTNEY M, YAWSON DK, MAGAGULA T and SESHOKA J (2004) Hydrology and Water Resources Development in the Olifants River Catchment. IWMI Working Paper 76. International Water Management Institute, Colombo, Sri Lanka, South Africa.

O'MEARA D (1983) Volkskapitalisme. Class, Capital and Ideology in the Development of Afrikaner Nationalism 193 - 1948. Ravan Press, Johannesburg, South Africa.

MOLLE F (2003) Development Trajectories of River Basins: A Conceptual Framework. IWMI Research Report 72. International Water Management Institute Colombo, South Africa.

POST-UITERWEER N, ZWARTEVEEN M, VELDWISCH GJ and VAN KOPPEN B (2006) Redressing Inequities through Domestic Water Supply: A 'Poor' Example from Sekhukhune, South Africa. In: Sylvain Perret, Stefano Farolfi and Rashid Hassan (eds.) Water Governance for Sustainable Development: Approaches and Lessons from Developing and Transitional Economies. London: Earthscan. 54-74.

REPUBLIC OF SOUTH AFRICA (1997) Water Services Act. Act 108 of 1997. Government Gazette No. 18522. Office of the President Cape Town, South Africa.

REPUBLIC OF SOUTH AFRICA (1998) National Water Act. Government Gazette Vol.398. 26 August 1998. Office of the President, Cape Town, South Africa.

SHAKER M (2005) Power Point presentation.

www.dpsa.gov.za/documents/networks/mpumalanga\%202005/Shaker. ppt

SPARKS A (1990) The mind of South Africa. The story of the rise and fall of apartheid. Jonathan Ball Publishers, Johannesburg and Cape Town, South Africa.

STATISTICS SOUTH AFRICA (2003) Census 2001: Statistics South Africa. Report no. 03-02-26(2001) Version 2, 2003, Pretoria, South Africa.

SAUNDERS C and SOUTHEY N (2001) A Dictionary of South African History ( $2^{\text {nd }}$ edn.) David Philip Publishers, Cape Town, South Africa.

TERREBLANCHE S (2002) A History of Inequality in South Africa 1652-2002. University of Natal Press, Pietermaritzburg, South Africa.

THOMPSON L (2001) A History of South Africa. Yale Note Bene Book, Yale University Press, New Haven and London.

TURTON AR, MEISSNER R, MAMPANE PM and SEREMO O (2004) A Hydropolitical History of South Africa's International River Basins. African Water Research Issues Unit, University of Pretoria, South Africa. WRC Report No 1220/1/04. Water Research Commission. Pretoria, South Africa.

VAN KOPPEN B, KHUMBANE T, DE LANGE M and MOHAPI N (2006) Gender and Agricultural Productivity: Implications for the Revitalization of Smallholder Irrigation Schemes Program in Sekhukhune District, South Africa. In: Kuntala Lahiri-Dutt (ed.) Fluid Bonds: Views on Gender and Water. Stree, Calcutta, India.

VAN REENEN RJ (1925) Development of irrigation in the Union of South Africa. S. Afr. J. Sci. 22.

VINK N and KIRSTEN J (2003) Agriculture in the national economy. In: Nieuwoudt, L and J Groenwald (eds.) 2003 The Challenge of Change. Agriculture, Land and the South African Economy. University of Natal Press, Pietermaritzburg, South Africa. 